\title{
An autochthonous Serbian product - Kajmak Characteristics and production procedures
}

\author{
Predrag PUdJA ${ }^{1 *}$, Jelena DJEROVSKI ${ }^{1}$, Mira RADOVANOVIć ${ }^{2}$ \\ ${ }^{1}$ University of Belgrade, Faculty of Agriculture, Institute of food technology \\ and biochemistry, Nemanjina 6, 11080 Belgrade, Serbia \\ ${ }^{2}$ Polimark, Ulica Oslobodjenja 29, Belgrade, Serbia
}

Received 3 September 2007 - Accepted 24 October 2007

\begin{abstract}
Kajmak is a dairy product with unique composition and sensory characteristics. It is formed from the thin, skin-like layer or crust formed on the surface of hot milk over a long cooling process, through milk fat aggregation with the significant participation of milk proteins. It can be consumed as a fresh kajmak immediately after production, or as a mature kajmak, after a substantial ripening period. Being an autochthonous Serbian dairy product, kajmak is believed to be one of the most prestigious and respectable dairy products that symbolizes domestic agriculture in this area of the world. The procedure of kajmak production is usually based on the traditional method of manufacture, which results in products of uneven composition and quality. Numerous steps in the procedure could represent potential safety risks for kajmak and the remaining milk. The sensory and compositional parameters of kajmak place this product between cheeses and butter in the classification of dairy products. The microflora of kajmak, which mainly originates from raw milk, plays a major role in the maturation process, particularly regarding texture and sensory profiles. The procedure for kajmak production developed in the food company "Polimark" is a promising solution for industrial kajmak production. The procedure covers all the steps that are included in traditional kajmak production, but the methodologies carried out are acceptable for industrial implementation. The use of lactic starters introduced in this industrial procedure may become a strategic tool for managing the ripening process and sensory characteristics of mature kajmak. Uncontrolled and unpredictable safety and sensory qualities regarding kajmak is certainly the main reason why such a delicious product has been left out of the world market and remains only significant on a local level. In this respect, the establishment of a modern, industrial kajmak production should represent a substantial improvement of the manufacturing conditions able to reduce the safety risks and to provide the conditions for commercializing a standard high-quality product.
\end{abstract}

\section{kajmak / composition / traditional production / industrial production / starter cultures}

摘要 - 塞尔维亚传统乳制品 kajmak 的性质和生产。Kajmak 是一种组成和感官性质独特 的乳制品。它是由热牛奶经过一个较长的冷却过程, 由于脂肪和蛋白质的凝聚作用, 在乳的 表面形成了一层薄皮, 或是形成一层硬壳。Kajmak 加工出来可以立即食用, 也可以成熟一 段时间后再食用。由于 kajmak 是塞尔维亚传统的乳制品, 在本土内享有极高的声誉, 它被认 为是塞尔维亚代表性的产品, 也是塞尔维亚国内农产品的象征。Kajmak 的生产通常采用传 统的制造方法, 因此, 使得产品的组成和质量不稳定。Kajmak 和残余的牛奶在加工过程中 存在着潜在的食品安全隐患。根据感官和组成参数, 在乳制品分类中, kajmak 介于干酪和奶 油之间。Kajmak 中的微生物主要来源于原料奶中,这些微生物在成熟过程中起着重要的作 用, 特别是对质地的形成和感官性质的改变起着重要的作用。Kajmak 的生产工艺经过不断 地改进, 已经能够实现工业生产。Kajmak 典型的工业化产品是 “Polimark”。尽管 Polimark

*Corresponding author (通讯作者): pudja@ agrifaculty.bg.ac.yu 
的生产包括了传统的 kajmak 生产的全部过程, 但是对每一加工步骤进行了改进使其能够实 现工业化生产。在工业生产中使用乳酸菌发酵剂来控制成熟过程和产品的感官特性。难以 控制和预测的食品安全问题和感官质量是使 kajmak 这种美味的食品只能在本土销售, 难以 进入国际市场的主要原因。若实现 kajmak 的现代化和工业化生产, 必须改进加工条件, 降低 食品安全危害, 制定产品的质量标准, 生产高品质的 kajmak 产品。

kajmak / 组成 / 传统产品 / 工业产品 / 发酵剂

Résumé - Un produit d'origine serbe, le kajmak : caractéristiques et procédés de production. Le kajmak est un produit laitier qui présente une composition et des caractéristiques sensorielles uniques. Il est obtenu à partir de la fine peau ou croûte qui se forme à la surface du lait chaud au cours du refroidissement, à laquelle s'agrège la matière grasse et une proportion significative des protéines laitières. Il peut se consommer frais, immédiatement après production, ou après une période d'affinage substantielle. Ce produit laitier typiquement serbe est considéré comme l'un des plus prestigieux et respectable symbolisant l'agriculture domestique dans cette région du monde. Le procédé de production du kajmak est majoritairement traditionnel et il conduit à des produits de composition et de qualité inégales. De plus, plusieurs étapes dans ce procédé présentent un risque potentiel de sécurité tant pour le kajmak que pour le lait restant. De par sa composition et ses caractéristiques sensorielles, le kajmak se situe entre les fromages et le beurre dans la classification des produits laitiers. La microflore du kajmak, qui provient principalement du lait cru, joue un rôle majeur au cours de la maturation, notamment sur la texture et les profils sensoriels. Le procédé développé par la société "Polimark" constitue une solution prometteuse de production industrielle du kajmak. Il reproduit toutes les étapes du procédé traditionnel, mais avec des méthodologies permettant une mise en œuvre industrielle. Avec l'emploi de levains lactiques introduit dans ce procédé industriel, il devient possible d'orienter le processus d'affinage et les caractéristiques sensorielles du kajmak affiné. Le non contrôle de la qualité sensorielle et les risques hygiéniques sont certainement les raisons principales pour lesquelles ce produit si délicieux a été exclu du marché mondial et n'est resté significatif qu'au niveau local. La mise en place d'une production industrielle moderne de kajmak devrait représenter une amélioration substantielle des conditions de fabrication, réduire le risque pour la santé et créer les conditions de commercialisation d'un produit standard de qualité élevée.

\section{kajmak / composition / production traditionnelle / production industrielle / levain}

\section{INTRODUCTION}

Kajmak is a dairy product with unique composition and sensory characteristics. It is formed from the thin, skin-like layer or crust formed on the surface of hot milk over a long cooling process through milk fat aggregation with the significant participation of milk proteins. Milk fat aggregates contribute to giving to kajmak some characteristics of butter. On the other hand, the presence of milk proteins, as well as their specific coagulation process during kajmak formation, relates kajmak to the cheese family, particularly to cream cheese varieties, that have a protein network as a base of their structure.
Production of kajmak and related products is associated with regions of Southeast Europe, and some Asian regions such as Turkey, Iran, Afghanistan and India [13].

In Serbia, kajmak is mainly produced from cow's milk but in some regions of Bosnia-Herzegovina and Montenegro, kajmak is sometimes produced from a mixture of cow's and ewe's milk, but rarely from ewe's milk exclusively. In Montenegro, kajmak is known under a different name - "skorup" $[3,4]$.

Manufacture and consumption of kajmak has a long tradition in Serbia. It may be consumed immediately after manufacture, as a fresh kajmak, or after a maturation period, as a ripened kajmak. 


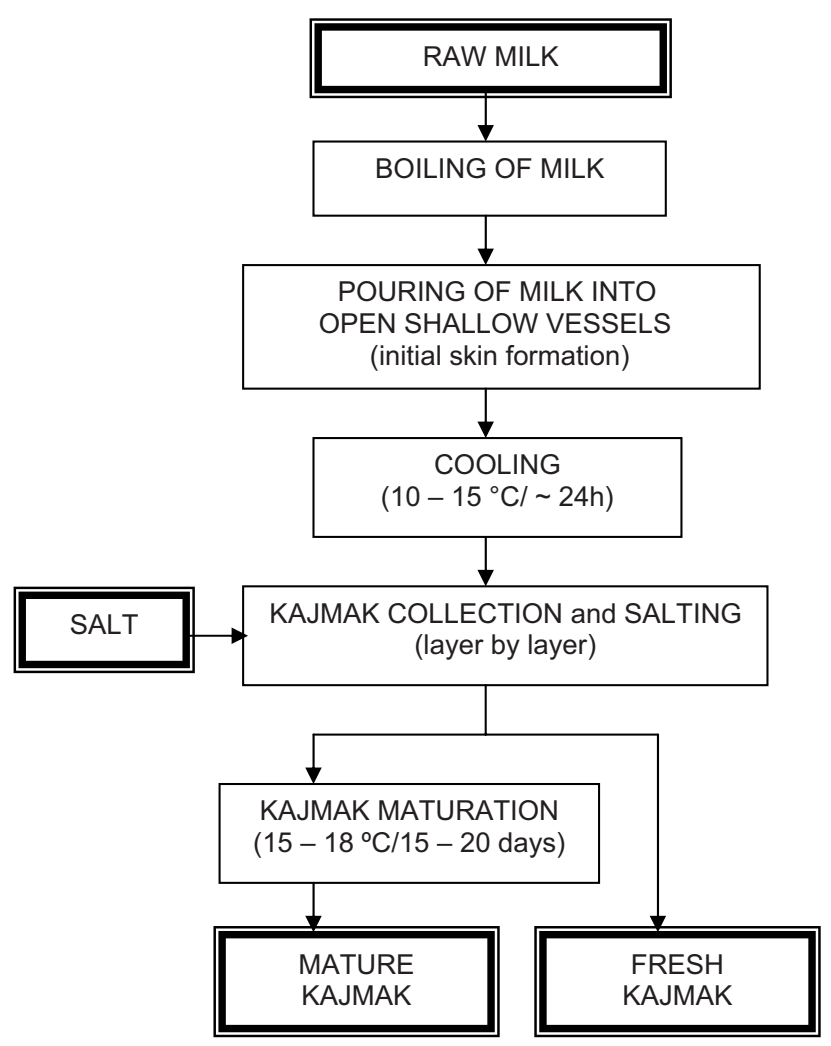

Figure 1. The procedure of traditional kajmak production.

Being an autochthonous Serbian dairy product, kajmak is believed to be one of the most prestigious and respectable dairy products that symbolizes domestic agriculture in this country.

Nowadays, kajmak is usually produced in households and small dairy craft plants. This autochthonous kajmak production is poorly organized and done in conditions which may involve substantial safety risks. Moreover, the manufacturing methods of kajmak production differ greatly from region to region, yielding products of uneven quality with wide variation in composition and characteristics $[1,3,4,8,12]$.

The appropriate industrial production procedure represents a solution for establishing a modern kajmak production. It is necessary for better positioning and distribution of kajmak on domestic and world markets, as well as for the creation of a distinguished Serbian brand in the group of dairy products.

\section{TRADITIONAL METHOD OF KAJMAK PRODUCTION}

The procedure of traditional kajmak production is shown in Figure 1.

This procedure is based on the surface activity of the top layer of boiled milk. Hot milk is poured into the open shallow vessels where, due to surface activity and evaporation, a kind of initial skin is formed on the top of the milk $[3,4,12]$. Important 
factors that control the process of initial skin formation are: milk composition, milk temperature, the humidity and temperature of the surrounding air, and the temperature difference between the milk and air.

After initial skin formation, a gradual process of milk cooling takes place and lasts about $24 \mathrm{~h}$, with a final temperature that ranges from 10 to $15{ }^{\circ} \mathrm{C}$. During the milk cooling process, fat globules rise up from the deeper milk layers and incorporate themselves into the previously formed initial skin. This action results in the formation of a thin, but compact layer known as kajmak. The kajmak formed on the top of the milk is collected, salted and, layer by layer, placed in appropriate vessels where maturation takes place. Traditional vessels for ripening are filled up with small portions of kajmak over several days. At the early stage of kajmak maturation, a little draining of the serum that separates from the bottom of the vessels takes place. Maturation of kajmak takes place at $15-18{ }^{\circ} \mathrm{C}$ over 15-20 days. Ripened kajmak, stored in cold conditions (below $8{ }^{\circ} \mathrm{C}$ ) may last 3-6 months, and in some cases up to one year $[3,4,12]$.

Yield of traditional kajmak production ranges from 4 to $5 \%$, depending on milk composition during lactation. Milk that remains after kajmak collection is partly skimmed and has a fat level of around 1.4$1.7 \%$ on average.

The remaining milk is traditionally used for production of half-fat white-brined cheese for the local market. Due to heat treatment applied to that milk, the cheesemaking process requires a higher coagulation temperature and longer coagulation time followed by mild curd treatment and consequent acidification.

Traditionally, kajmak and white cheese production on a farmhouse level represents a sort of package for milk processing, where the contributions of kajmak and cheese to the total income are, respectively, over $60 \%$ and less than $40 \%$.
Facilities for kajmak manufacture and production procedures vary widely from region to region, resulting in significant variation in kajmak composition and quality.

Traditional production includes numerous steps which represent potential safety risks for kajmak and the remaining milk such as: (i) the vast surface of the milk layer in contact with the surrounding air; (ii) the gradual, long-lasting process of milk cooling, with a very long period at a moderate temperature able to stimulate microbiological growth; and (iii) the low level of technical support and the transfer of the different products by hand.

\section{KAJMAK CHARACTERISTICS}

\subsection{Composition and structure}

Because of its physico-chemical characteristics, kajmak may be placed between cheese and butter. Fresh kajmak, like most unripened cheeses, is characterized by the continuity of its moisture phase, while milk fat mostly remains in its original globular form. Ripened kajmak, through the course of maturation, gradually changes its character. Indeed, during the maturation period, kajmak partly loses the continuity of its moisture phase, while a limited fat phase continuity appears. Partial suppression of its water phase continuity and its fragmentation, and the appearance of its fat phase continuity with light serum being expelled, result in compositional changes leading to moisture and protein decreases and to fat increase. Such compositional changes induce a reduction of hydrophilicity and consequently increase hydrophobicity, which in turn result in shifting kajmak's character from cheese to butter.

Kajmak's structure also undergoes substantial changes during ripening. The structure of fresh kajmak is not far from cream cheese structure. It is characterized by a laminated, uneven appearance, 
Table I. The average composition (\%) of butter, kajmak and cream cheese.

\begin{tabular}{|c|c|c|c|c|}
\hline \multirow[t]{2}{*}{ Parameter } & \multirow[t]{2}{*}{ Butter } & \multicolumn{2}{|c|}{ Kajmak } & \multirow{2}{*}{$\begin{array}{l}\text { Cream } \\
\text { cheese }\end{array}$} \\
\hline & & Fresh & Ripened & \\
\hline Moisture & 16 & $30-40$ & $15-35$ & $53-60$ \\
\hline Fat & 80 & $40-55$ & $50-70$ & $30-34$ \\
\hline Fat in DM & $>98$ & $65-80$ & 75-90 & 70 \\
\hline Proteins & 0.50 & $5-10$ & $2-7$ & $7-10$ \\
\hline Proteins in DM & 0.60 & $7-17$ & $3-10$ & 20 \\
\hline Salt & $0-1$ & $0.5-2$ & $1-3.5$ & $0.5-0.8$ \\
\hline
\end{tabular}

smooth body and good spreadability. Over the maturation period, kajmak's structure progressively changes from a laminar to granular structure with light serum separation. At extended maturation, up to one year, the granular kajmak structure undergoes further changes followed by additional serum separation, resulting in the formation of a uniform, butter-like structure. Structural changes are accompanied by improvement in spreadability as a result of the growing fat phase continuity and of moisture decrease.

Comparison of kajmak, cream cheese and butter composition also suggests the position of kajmak as a group within the various dairy products. The compositional parameters of cream cheese, butter and kajmak are mostly limited by the moisture and fat phase levels in these products (Tab. I).

Parameters for fat and moisture content of kajmak lie between the corresponding parameters for cream cheese and butter. The protein level of kajmak, particularly of fresh kajmak, is closer to cream cheese than to butter. During maturation, due to serum separation, kajmak's protein content decreases.

The salt content of kajmak, particularly ripened kajmak, is higher than in both cheese and butter. Further studies are required for a better understanding of salt's role in kajmak ripening in respect of texture change.

\subsection{Sensory characteristics}

Kajmak is a dairy product with unique sensory characteristics. Large differences in sensory characteristics within various kajmak samples are the result of uncontrolled and unstandardized traditional kajmak production.

The color of kajmak is mostly influenced by the ripening time, composition of milk fat and milk type. Fresh kajmak has a light color ranging from white to ivory. Over the maturation period, kajmak's color changes, like a number of ripened cheeses, from light to dark yellow. The use of ewe's milk in kajmak production results in a whiter product color.

The flavor of fresh kajmak is close to butter's flavor. It is a mild, creamy and milky flavor with a distinguished note, which appears in milk after it undergoes the boiling process. Mature kajmak has an intensive specific flavor enhanced by numerous volatile, aromatic compounds which result from proteolytic and lipolytic processes undergone during ripening [3, 12]. It may be concluded that the profile of kajmak flavor moves from butter to cheese during maturation. When ewe's milk is used in kajmak production, the aroma, particularly that of ripened kajmak, is much stronger because of the high content of short- and medium-chain fatty acids present in ewe's milk. Extramature kajmak, like hard Italian cheeses or Canadian Cheddar cheese, usually has 
a sharp flavor with a distinct note of rancidity.

The consistency and structure of fresh and mature kajmak vary widely. Fresh kajmak is characterized by a soft, creamy consistency and good spreadability. It has an uneven, laminated body with a gellike structure based on both fat and protein contents. Mature kajmak has a harder and grainy structure due to its higher total solids level. But it is more spreadable, due to the collapse of the protein structure and increased influence of the fat phase on its rheological behavior.

\subsection{Microbiological status}

The microflora present in traditionallyproduced kajmak mainly originates from raw milk and it is characteristic of the region where kajmak production takes place [12]. It is of great importance during the maturation period, particularly regarding changes in texture and sensory profiles. Consequently, as for numerous cheese varieties, kajmak ripening may be studied through the behavior of the endogenous microbial ecosystem during the time course of maturation.

The number and composition of autochthonous kajmak microflora are probably the significant factors that determine product quality and its sensory characteristics. High counts of lactic acid bacteria (LAB) were found in most of the samples that originate from different regions [1]. In these samples, lactobacilli and Cit+ bacteria rated about $10^{6} \mathrm{CFU} \cdot \mathrm{g}^{-1}$, while lactococci were at a higher level, ranging from $10^{6}$ to $10^{8} \mathrm{CFU} \cdot \mathrm{g}^{-1}$ [1].

In traditional kajmak production, due to poor manufacturing conditions, there is substantial room for uncontrolled growth and activity of endogenous microflora [1], leading to potential safety risks. Growth of undesirable flora may partly inhibit growth of desirable LAB, and consequently induce kajmak flavor defects.

This uncontrolled microbial growth leading to potential safety risks and flavor defects is likely the reason why such a delicious product has been left out of the world market and remains significant only on a local level. In this respect, the establishment of a modern, industrial kajmak production should be based on substantial improvement of the manufacturing conditions and introduction of starter cultures, in order to reduce the safety risks and provide the conditions for standardization of product quality.

\section{POTENTIAL PROCEDURE FOR INDUSTRIAL PRODUCTION}

The delicious organoleptic qualities and regional exclusiveness of kajmak have motivated numerous investigators to find an adequate solution to industrializing kajmak production and improving its market position. Such attempts $[2,10,11]$ were proposed, but unfortunately they did not succeed. A new procedure for kajmak production has been developed in the "Polimark $($ " company; it is a promising solution [6]. This procedure covers all steps included in traditional kajmak production, but they are realized by methods acceptable for industrial implementation and in such a way that they eliminate safety risks and enable standardization of kajmak production [7]. This procedure is shown in Figure 2.

It comprises evidently the two essential steps, i.e. hot incubation and cold agglutination, yielding the formation of upper and lower kajmak layers. Parameters that influence the formation of upper and lower kajmak layers are at a phase distance and the nature of their driving forces is completely different. In that respect, their characterization and optimization may be carried out separately. Initial 


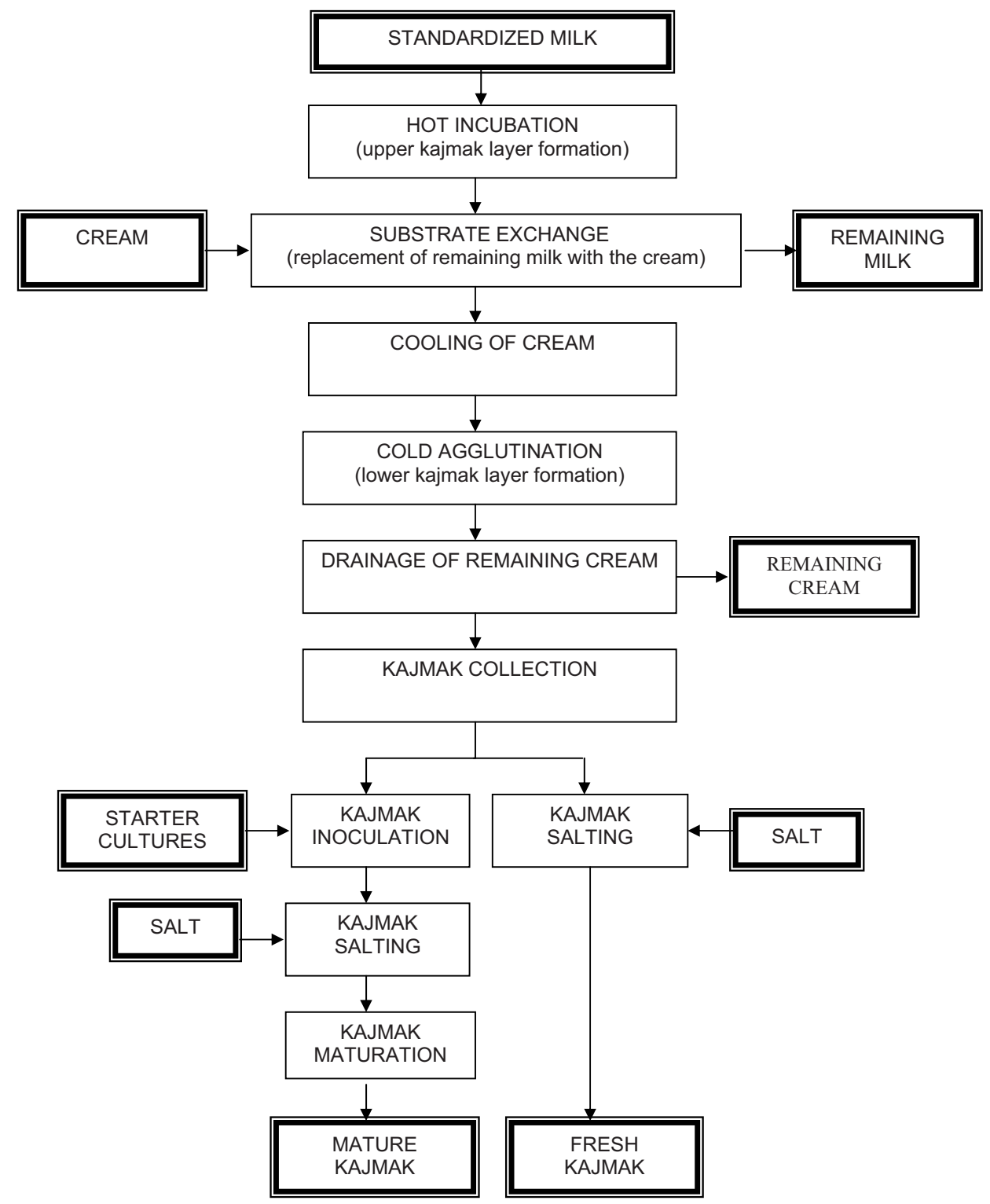

Figure 2. The procedure of industrial kajmak production. 
skin formation, the upper kajmak layer, due to surface tension and evaporation at the interface hot milk - air lasts 30-45 min. Conditioned air that flows over the milk surface during hot incubation removes the moisture that evaporates from the milk. Moisture evaporation is very intensive at the beginning of the hot incubation process, but later on, the skin formed on the milk surface substantially erases the level of further moisture evaporation.

The initial skin is a compact layer, lightly dried out, dominantly consisting of fat, but with the significant participation of proteins. Its composition is highly dependent on milk composition [8]. An increase in the fat and protein contents of the milk results in a remarkable increase in the fat and protein contents of the initial skin. By analyzing the mutual influence of these parameters, Pudja at al. [8] found that increase in milk protein content resulted in a noticeable increase in initial skin fat content, while increase in milk fat content had a negligible effect on the protein content of the initial skin.

When formation of the initial skin is completed, the exchange of the lower milk layer takes place as follows: the hot milk that remains below the initial skin is partly drained out and replaced with hot cream. Such an exchange must be done with caution in order to prevent potential damage to the initial skin previously formed. Shortly after this exchange, cooling of the cream without any disturbance takes place. The cooling process proceeds fast until the cream is cooled down to $20{ }^{\circ} \mathrm{C}$. Further cream cooling, i.e. cold agglutination, proceeds much more slowly, lasting about $2 \mathrm{~h}$, and yields formation of the lower kajmak layer. The lower kajmak layer has a soft, semi-solid consistency and an excessive spreadability, with fat as a dominant compositional fraction.

The exchange of the lower milk layer is an essential operation for shortening the kajmak formation process. In the tra- ditional production procedure milk fat droplets slowly incorporate themselves into the initial skin, due to the long time that is necessary for their concentration in the upper milk layer. In the industrial production procedure, after initial skin formation, fat droplet concentration increases instantly by substrate exchange, i.e. by removal of milk with a low fat level and replacement of it by hot cream. This creates the possibility of an increase in the cream cooling process rate and enables fast incorporation of fat droplets into the previously formed initial skin.

When the cold agglutination process is completed, the excess of cream is drained out and kajmak comprising both upper and lower layers is carefully collected, inoculated, salted and placed in the appropriate containers where maturation will take place. Kajmak is inoculated by dispersal of starters on the surface in the form of aerosol. If kajmak is intended to be used fresh, it is, without the inoculation, directly placed in final packaging and stored in cold conditions.

During the ripening process, which lasts 3-4 weeks, a specific flavor is developed. The shelf life of mature kajmak, in conditions that prevent aerobic microflora growth, can be 3-6 months.

Similar to cheese maturation, this industrial kajmak undergoes slow changes during extended storage. Sensory evaluation of mature kajmak over 14 weeks' storage showed a score of $73.9 \%$ of maximum quality at the beginning of the evaluation period, which increased upon extended storage to $89.7 \%$ at the end of the examination period [5]. The flavor of tested samples was characterized by a very "clean" flavor, a bit less strong than that of traditionally-produced kajmak. This so-called "clean" flavor likely arises from the dominance of the starter activity versus the role of NSLAB, as well as the absence of contamination, which is not 
the case with the traditionally-produced kajmak.

Pioneering steps in studying starter culture use in kajmak production indicate that the course of starters' growth in cheese and kajmak are quite similar. Radin et al. [9] investigated growth of commercial starter cultures (a mixture of $\mathrm{Lac}$ tococcus lactis ssp. lactis, Lc. lactis ssp. cremoris, Lc. lactis ssp. lactis biovar diacetylactis and Leuconostoc mesenteroides ssp. cremoris) over one month of kajmak ripening. Maximum growth of the added starters (about $10^{8} \mathrm{CFU} \cdot \mathrm{g}^{-1}$ ) during maturation at $18{ }^{\circ} \mathrm{C}$ and $12{ }^{\circ} \mathrm{C}$ was, respectively, reached after two and 15 days.

Future research in application of starter cultures in kajmak production should be directed at defining the strains that are most important for obtaining characteristic kajmak flavor formation, in order to match as much as possible the flavor profile of traditionally-produced kajmak. In that respect, special attention should be paid to Cit+ strains, as well as to starters with peptidase activity.

The industrial procedure provides production of kajmak that fully matches safety requirements. Reduction of the total production course period, especially time needed for the cream cooling process, minimizes the possibility of undesirable microflora development in both kajmak and its by-products. Unlike traditional production, the milk surface is treated by airconditioning, which eliminates most of the recontamination by environmental air. Furthermore, remaining by-products may be used for production of a wide range of dairy products, while, in traditional production, the use of the remaining milk is restricted only to production of a particular cheese type: that is, half-fat white cheese. Standardization of the milk and cream used as starting materials, as well as the process parameters regarding formation of both upper and lower kajmak layers (temperatures of different media, air humidity, etc.), make it possible to get a fresh product of standardized composition, structure and sensory characteristics. The introduction of starters in the course of kajmak production may become a strategic tool for managing the ripening process and sensory characteristics of mature kajmak.

\section{CONCLUSION}

The composition, sensory properties and microbiological status of kajmak are unique and lie between the relevant parameters of cheeses and butter.

Production of kajmak is carried out as a homemade manufacture, based on the traditional manufacturing procedure. Traditionally-produced kajmak differs greatly from producer to producer and yields wide variation in product composition, characteristics and quality. The process used comprises numerous steps that represent potential safety risks for consumption of kajmak as well as the remaining milk.

The new patented procedure is suitable for industrial application. Its major advantages are: significant shortening of the production time, the use of starters, good prospects for processing control, full bacteriological safety and composition and characteristics that are quite close to traditionally-produced kajmak.

\section{REFERENCES}

[1] Djerovski J., Radulović Z., Radin D., Radovanović M., Pudja P., Investigation of kajmak quality: Chemical, microbiological and sensory aspect, Food Ind. Milk Dairy Prod. 17 (2006) 25-28.

[2] Djordjević J., Postupak za industrijsku proizvodnju mladog kajmaka, Yugoslav Patent 45484, Intellectual Property Office, Belgrade, Serbia, 1992.

[3] Dozet N., Adžić N., Stanišić M., Živić N., Autochthonous dairy products, Agriculture Institute, Podgorica, Montenegro, 1996, pp. 131-149. 
[4] Pejić O., Skorup-Kajmak, in: Dairy technology - II part. Naučna knjiga, Belgrade, Serbia, 1956, pp. 506-509.

[5] Pudja P., Radovanović M., Industrial kajmak production. Composition and sensory characteristics, in: Symposium «Milk and dairy products », 25-29 April, Zlatibor, Serbia, Faculty of Agriculture, Belgrade, Serbia, Proceedings, 2004, pp. 253-255.

[6] Pudja P., Starčević V., Radovanović M., A procedure for industrial production of traditional quality kajmak and kajmak produced thereof, Patent - 683/02, Intellectual Property Office, Belgrade, Serbia, 2002.

[7] Pudja P., Radovanović M., Starčević V., Production procedure of traditional quality kajmak in the industrial conditions, Food Ind. Milk Dairy Prod. 15 (2004) 15-20.

[8] Pudja P., Radovanović M., Starčević V., Mioćinović J., Kajmak composition and characteristics. I. Influence of milk composition on skin formation, Biotechnol. Anim. Husb. 21 (2005) 175-187.

[9] Radin D., Djerovski J., Radulović Z., Radovanović M., Pudja P., The maturation of kajmak in the controlled conditions, Food Ind. Milk Dairy Prod. 16 (2005) 60-65.

[10] Starčević V., Postupak i postrojenje za industrijsku proizvodnju kajmaka, Yugoslav Patent Application 1594/88, Intellectual Property Office, Belgrade, Serbia, 1988.

[11] Stević B., Postupak za proizvodnju kajmaka, Yugoslav Patent Application 56/54, Intellectual Property Office, Belgrade, Serbia, 1954.

[12] Stević B., Tehnološka mikrobiologija stočnih proizvoda i ishrane stoke, Naučna knjiga, Belgrade, Serbia, 1962, pp. 176-180.

[13] www.en.wikipedia.org/wiki/Kajmak 